\title{
$\begin{gathered}\text { Jurnal Bahasa, Sastra Indonesia, dan Pengajarannya } \\ \text { Volume 1- Nomor 2, April 2018, (HIm 127-142) }\end{gathered}$
Available online at: http://sasando.upstegal.ac.id
}

\section{PEMAHAMAN DAN KESIAPAN GURU MATA PELAJARAN BAHASA INDONESIA SMK KABUPATEN TEGAL DALAM MENDUKUNG IMPLEMENTASI KURIKULUM 2013}

\author{
Ghufroni \\ Program Studi Pendidikan Bahasa dan Sastra Indonesia, Universitas Muhadi Setiabudi Brebes. \\ Jalan Pangeran Diponegoro KM 2 Wanasari Brebes, Jawa Tengah, 52221 Indonesia. Email: \\ umus@umus.ac.id Website: http://umus.ac.id .*Korespondensi Penulis. Email: \\ ghufronironi@gmail.com Telepon: 08564055 6183/0895 358163781
}

\begin{abstract}
Abstrak
Penelitian ini bertujuan untuk mengetahui pemahaman dan kesiapan guru mata pelajaran Bahasa Indonesia SMK Kabupaten Tegal dalam mengimplementasikan Kurikulum 2013. Penelitian ini merupakan penelitian kuantitatif deskriptif. Responden dalam penelitian ini adalah guru mata pelajaran Bahasa Indonesia SMK Kabupaten Tegal yang telah mengimplementasikan Kurikulum 2013. Hasil penelitian menunjukkan bahwa pemahaman Guru terhadap Kurikulum 2013 masuk kategori sedang, yaitu sebanyak 12 guru ( $48 \%$ ). Guru yang masuk dalam kategori rendah sebanyak 8 guru (32\%), dan guru yang masuk dalam kategori tinggi sebanyak 5 guru (20\%). Sedangkan kesiapan guru dalam mendukung implementasi Kurikulum 2013 masuk kategori sedang, yaitu sebanyak 13 guru (52 \%). Guru masuk dalam kategori rendah sebanyak 10 guru ( 40 \%) dan guru yang masuk dalam kategori tinggi sebanyak 2 guru (8\%). Dapat disimpulkan bahwa pemahaman dan kesiapan guru dalam mendukung implementasi Kurikulum 2013 adalah sedang.
\end{abstract}

\section{Kata kunci : Pemahaman, Kesiapan dan Kurikulum 2013}

\begin{abstract}
This study aims to determine the understanding and readiness of Indonesian Vocational School teachers in Tegal Regency in implementing the 2013 Curriculum. This research is a quantitative descriptive study. Respondents in this study were teachers of Indonesian Language Vocational School in Tegal Regency who had implemented the 2013 Curriculum. The results showed that Teacher's understanding of Curriculum 2013 was in the moderate category, namely as many as 12 teachers (48\%). Teachers who were included in the low category were 8 teachers (32\%), and teachers who were included in the high category were 5 teachers (20\%). While the readiness of teachers to support the implementation of the 2013 Curriculum is in the moderate category, namely as many as 13 teachers (52\%). Teachers fall into the low category as many as 10 teachers (40\%) and teachers who fall into the high category are 2 teachers (8\%). It can be concluded that the teacher's understanding and readiness in supporting the implementation of the 2013 curriculum are moderate.
\end{abstract}

Keywords: Understanding, Readiness and Curriculum 


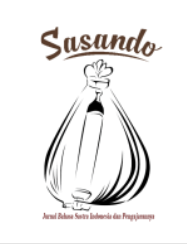

\section{Jurnal Bahasa, Sastra Indonesia, dan Pengajarannya \\ Volume 1- Nomor 2, April 2018, (HIm 127-142)}

Available online at: http://sasando.upstegal.ac.id

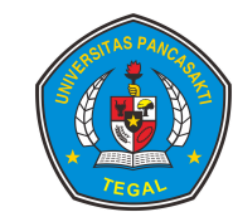

\section{PENDAHULUAN}

Pendidikan di sekolah pada dasarnya merupakan proses pendidikan yang diorganisasikan secara formal berdasarkan struktur hirarkis dan berjenjang. Berlangsungnya proses pendidikan di sekolah sangat bergantung pada keberadaan subsistem-subsistem lain yang terdiri atas peserta didik, manajemen penyelenggaraan sekolah, struktur dan kegiatan belajar-mengajar, materi atau bahan pengajaran yang diatur dalam seperangkat sistem yang disebut kurikulum.

Pengembangan kurikulum 2013 dilakukan karena adanya faktor-faktor rasionalitas yang melandasinya. Sebagaimana tertuang dalam Salinan Lampiran I Peraturan menteri pendidikan dan kebudayaan Nomor 60 tahun 2014 Tentang Kurikulum 2013 sekolah menengah kejuruan/madrasah aliyah kejuruan, terdapat lima faktor yang mendasari pengembangan kurikulum 2013: 1) Tantangan internal, 1) Tantangan eksternal, 3) Penyempurnaan pola pikir, 4) Penguatan tata kelola kurikulum, dan 5) Penguatan materi (Permendikbud: 2014).

\begin{tabular}{|c|c|c|}
\hline Dalam & kaitannya & dengan \\
\hline implementasi & kurikulum & 2013, \\
\hline
\end{tabular}

(Sekolah Menengah Kejuruan) di Kabupaten Tegal belum terukur sesuai dengan harapan Pemerintah dan masyarakat Indonesia. Sehingga penelitian ini muncul permasalahan ; bagaimakanah pemahaman dan kesiapan Guru mata pelajaran Bahasa Indonesia SMK Kabupaten Tegal ? dan tujuan penelitian ini untuk mengetahui sejauhmana pemahaman dan kesiapan Guru SMK Kabupaten Tegal dalam mengimplementasikan kurikulum 3013.

Penelitian ini memberikan penilaian terhadap kemampuan guru terhadap konsep kurikulum 2013 (aspek teoritis) yang meliputi: pemahaman terhadap buku teks (buku siswa dan buku guru), pemahaman terhadap penyusunan rencana pelaksanaan pembelajaran, pemahaman terhadap pelaksanaan pembelajaran, dan pemahaman terhadap pelaksanaan penilaian hasil belajar. Sedangkann dari segi kesiapan dalam penelitian ini dilakukan dengan memberikan penilaian terhadap guru tentang kesiapannya dalam melaksanakan kurikulum 2013 (aspek praktis) yang meliputi; kesiapan untuk menggunakan buku teks (buku siswa dan buku guru), kesiapan untuk menyusun rencana pelaksanaan pembelajaran, kesiapan untuk melaksanaan pembelajaran, dan kesiapan untuk melaksanaan penilaian 


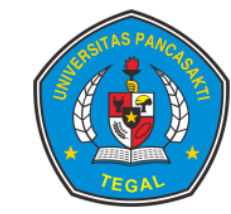

(analisis penilaian serta pengayaan dan perbaikan).

Dengan demikian hasil penelitian diharapkan dapat menghasilkan manfaat yaitu dapat memberikan sumbangan pemikiran dan tolok ukur kajian pada penelitian lebih lanjut yaitu berupa perbaikan pembelajaran kurikulum 2013 yang dapat dipertimbangkan dalam usaha memperbaiki mutu pendidikan dan mempertinggi interaksi belajar mengajar,khususnya dalam

pembelajaran kurikulum 2013.

Penelitian ini mengetahui seberapa besar pemahaman dan kesiapan guru bahasa Indonesia dalam mengimplementasikan kurikulum 2013. Di samping itu, untuk mengetahui faktorfaktor kelebihan dan kekurangan dalam kurikulum 2013. Penelitian ini diharapkan dapat memberikan sumbangan konsep teoritis dan pengetahuan dalam penerapan suatu penelitian tentang implementasi kurikulum 2013 terutama di Kabupaten Tegal.

Selain itu diharapkan dapat dijadikan bahan pertimbangan dalam rangka memajukan dan meningkatkan mutu pendidikan melalui guru bahasa Indonesia dalam prestasi sekolah yang dapat disampaikan dalam pembinaan guru ataupun kesempatan lain bahwa pembelajaran melalui kurikulum 2013 merupakan bahan pencapaian hasil belajar yang maksimal, sehingga guru dapat melakukan perubahan maindshet dalam pembelajaran kurikulum 2013.

Penelitian tentang Pemahaman dan Kesiapan Guru Bahasa Indonesia dalam mendukung implementasi kurikulum 2013 merupakan penelitian yang menarik dilakukan, karena penelitian ini pernah dilakukan oleh Indah Pertiwi (2015) dan Daniel Bagas Setyawan (2014)dalam mata pelajaran yang berbeda-beda, objek penelitian yang berbeda. Sehingga dalam penelitian ini berbeda dengan penelitian sebelumnya.

Kerangka berpikir dalam penelitian ini didasarkan pada rasionalitas pengembangan kurikulum 2013. Ada lima faktor yang mendasari

pengembangan kurikulum 2013: 1) Tantangan internal, 2) Tantangan eksternal, 3) Penyempurnaan pola pikir, 4) Penguatan tata kelola kurikulum, dan 5) Penguatan materi.

\section{A. METODE}

\section{Jenis Penelitian}

Penelitian ini termasuk penelitian lapangan (field reseach) yaitu penelitian yang pengumpulan datanya dilakukan di lapangan. Penelitian pendidikan mempunyai kancah bukan saja di sekolah tetapi dapat di keluarga, di masyarakat, di pabrik, di rumah sakit. Sedangkan jenis penelitian ini adalah penelitian kuantitatif yaitu penelitian yang menggunakan angka, mulai dari pengumpulan data, penafsiran terhadap data tersebut, serta 
penampilan dari hasilnya (Arikunto, 2002: 9).

Berdasarkan teori penelitian kuantitatif tersebut, data yang diperoleh dari responden dianalisis dengan menggunakan metode penghitungan statistik terhadap pemahaman dan kesiapan guru mata pelajaran Bahasa Indonesia Sekolah Menengah Kejuruan (SMK) Kabupaten Tegal dalam mendukung implementasi Kurikulum 2013.

\section{Waktu dan Tempat Penelitian}

Penelitian ini dilaksanakan di SMK se-Kabupaten Tegal yang telah mengimplementasikan kurikulum 2013, sedangkan waktu pelaksanaan penelitian dilaksanakan pada bulan Agustus sampai November 2017

\section{Target/Subjek Penelitian} Subjek dalam penelitian adalah pemahaman dan kesiapan Guru Bahasa Indonesia. Adapun sumber datanya adalah Guru Bahasa Indonesia SMK Kabupaten Tegal Tahun Pelajaran 2017/2018 dengan populasi 4 SMK yang mengimplementasikan kurikulum 2013, yaitu 1) SMK N 1 Adiwerna 2) SMK N 2 Adiwerna 3) SMK N Dukuhturi 4) SMK N 1 Slawi. Jumlah keseluruhan 25 guru bahasa Indonesa.

Variabel penelitian ini meliputi dua variabel, yaitu Pemahaman dan kesiapan Guru Bahasa Indonesia dalam implementasi kurikulum 2013.

\section{Prosedur}

Prosedur pelaksanaan penelitian ini melalui beberapa tahapan perencanaan, mengumpulkan data (tes, dokumen, observasi dan wawancara), Selanjutnya melakukan penyusunan instrumen penelitian dengan melakukan validasi instrumen dan berlanjut menganalisis deskripsi data responden dalam penelitian meliputi jenis kelamin, usia, tingkat pendidikan, dan masa kerja, status PNS dan sertifikasi. Juga menganalisis deskripsi pemahaman dan kesiapan guru terhadap buku teks, RPP, pelaksanaan pembelajaran, pelaksanaan penilaian hasil belajar dalam kurikulum 2013.

Proses penelitian akhir dilaksanakan Crosstabulasi data pemahaman dan kesiapan pada jenis kelamin, usia, masa kerja, tingkat pendidikan, status PNS dan sertifikasi.

\section{$5 . \quad$ Data, Instrumen, dan Teknik Pengumpulan Data}

Dalam penelitian ini penyusun menggunakan penelitian lapangan (field reseach) yaitu penelitian yang pengumpulan datanya dilakukan di lapangan atau di 4 SMK Kabupaten Tegal sejumah 25 guru Bahasa Indonesia dengan teknik pengumpulan data : (1) Tes (2) Dokumen (3) Observasi (4) Wawancara. Selanjutnya untuk menjaring data-data tersebut, peneliti mengembangkan instrumen tes, 


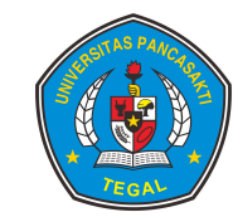

instrumen observasi dan pedoman wawancara. Instrumen tes dan instrumen observasi dalam penelitian ini lebih difokuskan untuk menemukan jawaban atas pertanyaan penelitian pertama dan kedua yakni pemahaman dan kesiapan guru terhadap Kurikulum 2013. Sedangkan pedoman wawancara dimaksudkan untuk menemukan jawaban atas pertanyaan penelitian yang ketiga yakni tentang faktor-faktor pendukung dan

\section{penghambat implementasi}

Kurikulum 2013.

Berdasarkan teori penelitian deskriptif kuantitatif, data yang diperoleh dari responden dianalisis dengan

menggunakan metode penghitungan statistik.

\section{Teknik Analisis Data}

Data yang sudah diperoleh melalui

(1) Tes (2) Dokumen (3) Observasi dan

(4) Wawancara, selanjutnya disusun instrumen penelitian yang kemudian dilakukan uji validitas dan uji realibilitas instrumen. Data yang sudah lengkap kemudian dilakukan analisis statistik deskriptif. Analisis deskriptif bertujuan untuk mendeskripsikan atau menjelaskantentang gambaran yang diteliti berdasarkan data dari variabel yang diperoleh, dan tidak dimaksudkan untuk pengujian hipotesis. Penyajian hasil analisis deskriptif berupa frekuensi dan persentase, tabulasi silang, berbagai bentuk grafik dan chart pada data yang bersifat kategorikal, serta berupa statistik-statistik kelompok seperti nilai rata-rata (mean) (Azwar, 2015: 126).

Pengkategorian skor dari masingmasing aspek tersebut kemudian dikelompokan ke dalam tiga kategori. Pengkategorian dilakukan berdasarkan rata-rata ideal (M) dan standar deviasi (SD) pada masing- masing aspek. Azwar (2015: 149) membagi kecenderungan tiap aspek menjadi tiga kategori sebagai berikut:

Tabel 1. Pedoman Pengkategorian

\begin{tabular}{|c|c|c|}
\hline No & Kategori & Skor \\
\hline 1 & Tinggi & $\mathrm{X} \geq \mathrm{M}+\mathrm{SD}$ \\
\hline 2 & Sedang & $\mathrm{M}-\mathrm{SD} \leq \mathrm{X}<\mathrm{M}+$ \\
\hline 3 & Rendah & $\mathrm{X}<\mathrm{M}-\mathrm{SD}$ \\
\hline
\end{tabular}

Keterangan:

$\mathrm{M}($ Mean Ideal $)=1 / 2($ skor tertinggi + skor terendah)

SD $($ Standar Deviasi Ideal $)=1 / 6$

(skor tertinggi - skor terendah) X

= Skor yang dicapai responden

(guru)

Selanjutnya cara menentukan analisis data yaitu dengan mencari besarnya relative persentase, dengan rumus sebagai berikut: f : Frekuensi

N : Jumlah Populasi

Setelah data dianalisis, maka untuk mengetahui kecenderung 
an hubungan antar variabel digunakan analisis crosstabs (tabulasi silang). Pada penelitian ini analisis crosstabs digunakan untuk menyilangkan data dengan jenis kelamin, usia, pendidikan, masa kerja, Status PNS dan status sertifikasi terhadap tingkat pemahaman dan kesiapan guru dalam mendukung implementasi Kurikulum 2013.

\section{B. HASIL DAN PEMBAHASAN}

Di Kabupaten Tegal ada 4 sekolah Menengah Kejuruan yang mengimplementasikan Kurikulum 2013 sejak tahun pertama (2013/2014). Sekolah-sekolah tersebut Merupakan pionir atau sekolah sasaran sebagai uji coba implementasi Kurikulum 2013. Pada tahunpertama implementasi dilaksanakan pada kelas $\mathrm{X}$ dan pada tahun pelajaran berikutnya $\quad(2017 / 2018)$ diterapkan secara menyeluruh kelas X sampai dengan kelas XII.

Sedangkan profil guru dari 4 SMK se-Kabupaten Tegal berjumlah 25 orang Guru Mata Pelajaran Bahasa Indonesia dengan rincian sebagai berikut:

1. SMK Negeri 1 Adiwerna sejumlah 9 orang

2. SMK Negeri 2 Adiwerna sejumlah 5 orang

3. SMK Negeri 1 Slawi sejumlah 5 orang

4. SMK Negeri 1 Dukuhturi sejumlah 6 orang.
Keterangan:

P : Persentase dalam implementasi Kurikulum 2013 Berdasarkan pada data responden yang diperoleh bahwa Pemahaman dan Kesiapan guru Bahasa Indonesia Sekolah Menengah Kejuruan seKabupaten Tegal dalam mendukung Implementasi Kurikulum 2013 dilihat dari 4 komponen. Komponen pertama adalah pemahaman dan kesiapan guru dalam implementasi buku teks, Komponen kedua yaitu pemahaman dan kesiapan guru dalam implementasi rencana pelaksanaan pembelajaran, komponen ketiga yaitu pemahaman dan kesiapan guru dalam implementasi pelaksanaan pembelajaran dan komponen keempat yaitu pemahaman dan kesiapan guru dalam implementasi penilaian hasil belajar.

Penghitungan hasil penelitian menunjukkan bahwa secara keseluruhan pemahaman guru terhadap Kurikulum 2013 masuk dalam kategori sedang sebesar $48 \%$ sesuai dengan tebel sebagai berikut:

Tabel 2. Pemahaman Guru Terhadap Kurikulum 2013

\begin{tabular}{|c|c|c|c|c|}
\hline No & Kategori & Skor & F & $\begin{array}{c}\text { Frekuensi Relatif } \\
(\%)\end{array}$ \\
\hline 1 & Tinggi & $\mathrm{X} \geq 57$ & 5 & $20 \%$ \\
\hline 2 & Sedang & $46 \leq \mathrm{X}<57$ & 12 & $48 \%$ \\
\hline 3 & Rendah & $\mathrm{X}<46$ & 8 & $32 \%$ \\
\hline \multicolumn{3}{|c|}{ Jumlah } & 25 & $100 \%$ \\
\hline
\end{tabular}

Sedangkan kesiapan guru dalam mendukung implementasi Kurikulum 2013 masuk dalam kategori sedang sebesar $52 \%$ sesuai dengan tabel sebagai berikut:

Tabel 3. Kesiapan Guru Untuk Mendukung Implementasi 


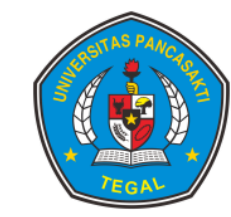

Kurikulum 2013

\begin{tabular}{|c|c|c|c|c|}
\hline 2 & Sedang & $65 \leq X<83$ & 13 & $52 \%$ \\
\hline 3 & Rendah & $X<65$ & 10 & $40 \%$ \\
\hline \multicolumn{3}{|c|}{ Jumlah } & 25 & $100 \%$ \\
\hline
\end{tabular}

hasil penelitian menunjukkan bahwa secara umum guru sudah memahami Kurikulum 2013 dan siap melaksanakan implementasi kurikulum 2013 meskipun masih dalam kategori sedang dan belum mencakup keseluruhan materi Kurikulum

2013.

Adapaun rincian perhitungan data hasil penelitian, pemahaman dan kesiapan guru terhadap Kurikulum 2013 yang meliputi pemahaman dan kesiapan terhadap buku teks, pemahaman terhadap rencana pelaksanaan pembelajaran, pemahaman terhadap pelaksanaan pembelajaran dan pemahaman terhadap penilaian hasil belajar sebagai berikut:

1. Pemahaman dan Kesiapan Guru terhadap Buku Teks sesuai dengan tabel di bawah ini:

Tabel 4. Pemahaman Guru terhadap Buku Teks

\begin{tabular}{|c|c|c|c|c|}
\hline No & Kategori & Skor & $\mathrm{F}$ & $\begin{array}{l}\text { Frekuensi } \\
\text { Relatif (\%) }\end{array}$ \\
\hline 1 & Tinggi & $X \geq 57$ & 5 & $20 \%$ \\
\hline 2 & Sedang & $33 \leq X<57$ & 13 & $52 \%$ \\
\hline 3 & Rendah & $X<33$ & 7 & $28 \%$ \\
\hline \multicolumn{3}{|c|}{ Jumlah } & 25 & $100 \%$ \\
\hline
\end{tabular}

Sesuai dengan tabel di atas dapat diketahui bahwa pemahaman Guru Bahasa Indonesia terhadap buku teks masuk dalam kategori sedang yaitu sebanyak 13 Guru atau 52\%. Sedangkan kesiapan Guru dalam menggunakan Buku Teks sesuai tabel di bawah ini:

Tabel 5. Kesiapan Guru Untuk

Menggunakan Buku

Tabel di atas menunjukkan bahwa kesiapan Guru dalam menggunakan Buku Teks masuk kategori sedang sebanyak 19 orang atau $76 \%$. Dengan demikian buku teks pelajaran dan buku panduan guru untuk pendidikan dasar dan menengah di atur dalam Permendikbud Nomor 71 Tahun 2013 dan Permendikbud Nomor 65 Tahun 2013 tentang standar proses pendidikan dasar dan menengah juga dijelaskan tentang buku teks pelajaran yang mana buku teks pelajaran merupakan buku yang digunakan untuk meningkatan efisiensi dan efektivitas yang jumlahnya disesuaikan dengan kebutuhan peserta didik.

2. Pemahaman dan Kesiapan Guru terhadap Rencana Pelaksanaan Pembelajaran sesuai dengan tabel di bawah ini:

Tabel 6. Pemahaman Guru terhadap Rencana Pelaksanaan Pembelajaran

\begin{tabular}{|c|c|c|c|c|}
\hline No & Kategori & Skor & $\mathrm{F}$ & $\begin{array}{l}\text { Frekuensi Relatif } \\
\quad(\%)\end{array}$ \\
\hline 1 & Tinggi & $X \geq 47$ & 10 & $40 \%$ \\
\hline 2 & Sedang & $33 \leq X<47$ & 10 & $40 \%$ \\
\hline 3 & Rendah & $\mathrm{X}<33$ & 5 & $20 \%$ \\
\hline \multicolumn{3}{|c|}{ Jumlah } & 25 & $100 \%$ \\
\hline
\end{tabular}

Pemahaman guru terhadap rencana pelaksanaan pembelajaran masuk dalam kategori sedang dan tinggi yaitu masingmasing 10 orang atau sebesar $40 \%$. Sedangkan Kesiapan guru dalam Menyusunan Rencana Pelaksanaan 
Pembelajaran sesuai tabel di bawah ini:

\begin{tabular}{|l|c|c|c|c|}
\multicolumn{3}{|c}{ Tabel 7. Kesiapan Guru } \\
\hline $\begin{array}{l}\text { Meny } \\
\text { usun } \\
\text { Renca } \\
\text { na } \\
\text { Pelaks } \\
\text { anaan } \\
\text { Pembe } \\
\text { lajaran } \\
\text { No }\end{array}$ & Kategori & Skor & F & $\begin{array}{c}\text { Frekuensi Relatif } \\
(\%)\end{array}$ \\
\hline 1 & & & & \\
\hline 2 & Tinggi & $\mathrm{X} \geq 83$ & 10 & \\
\hline
\end{tabular}

Tabel di atas menunjukkan bahwa kesiapan Guru dalam menyusun Rencana Pelaksanaan

Pembelajaran masuk kategori sedang sebanyak 11 orang atau 44\%. Dalam Permendikbud Nomor 65 Tahun 2013 tentang standar proses pendidikan dasar dan menengah dijelaskan bahwa rencana pelaksanaan pembelajaran (RPP) adalah rencana kegiatan pembelajaran tatap muka untuk satu pertemuan atau lebih. RPP dikembangkan dari silabus untuk mengarahkan kegiatan pembelajaran peserta didik dalam upaya mencapai Kompetensi Dasar (KD). Setiap pendidik pada satuan pendidikan berkewajiban menyusun RPP secara lengkap dan sistematis agar pembelajaran

berlangsung secara interaktif, inspiratif, menyenangkan, menantang, efisien, memotivasi peserta didik untuk berpartisipasi aktif, serta memberikan ruang yang cukup bagi prakarsa, kreativitas, dan kemandirian sesuai dengan bakat, minat, dan perkembangan fisik serta psikologis peserta didik.
3. Pemahaman dan Kesiapan Guru terhadap

Pelaksanaan Pembelajaran sesuai dengan tabel di bawah ini:

Tabel 8. Pemahaman Guru terhadap Pelaksanaan Pembelajaran

\begin{tabular}{|c|c|c|c|c|}
\hline No & Kategori & Skor & F & $\begin{array}{c}\text { Frekuensi Relatif } \\
(\%)\end{array}$ \\
\hline 1 & Tinggi & $\mathrm{X} \geq 63$ & 10 & $40 \%$ \\
\hline 2 & Sedang & $47 \leq \mathrm{X}<63$ & 6 & $24 \%$ \\
\hline
\end{tabular}

\section{Pemahaman guru}

terhadap

pelaksanaan pembelajaran masuk dalam kategori tinggi sebanyak 10 orang atau sebesar $40 \%$. Sedangkan Kesiapan Guru dalam Melaksanaan Pembelajaransesuai tabel di bawah ini:

\begin{tabular}{|c|c|c|c|c|}
\hline No & Kategori & Skor & $\mathrm{F}$ & $\begin{array}{c}\text { Frekuensi Relatif } \\
(\%)\end{array}$ \\
\hline 1 & Tinggi & $X \geq 77$ & 6 & $24 \%$ \\
\hline 2 & Sedang & $53 \leq X<77$ & 17 & $68 \%$ \\
\hline 3 & Rendah & $\mathrm{X}<53$ & 2 & $8 \%$ \\
\hline \multicolumn{3}{|c|}{ Jumlah } & 25 & $100 \%$ \\
\hline
\end{tabular}

Tabel di atas menunjukkan bahwa Kesiapan Guru dalam melaksanakan Pembelajaran masuk kategori sedang sebnyak 17 orang atau sebesar 68\%. Dalam Permendikbud Nomor 65 Tahun 2013 tentang standar proses pendidikan dasar dan menengah dijelaskan bahwa rencana pelaksanaan pembelajaran (RPP) adalah rencana kegiatan pembelajaran tatap muka untuk satu pertemuan atau lebih. RPP

dikembangkan dari silabus untuk mengarahkan kegiatan pembelajaran 
peserta didik dalam upaya mencapai Kompetensi Dasar (KD). Setiap pendidik pada satuan pendidikan berkewajiban menyusun RPP secara lengkap dan sistematis agar pembelajaran

berlangsung secara interaktif, inspiratif, menyenangkan, menantang, efisien, memotivasi peserta didik untuk berpartisipasi aktif, serta memberikan ruang yang cukup bagi prakarsa

, kreativitas, dan kemandirian sesuai dengan bakat, minat, dan perkembangan fisik serta psikologis peserta didik. RPP disusun berdasarkan KD atau sub tema yang dilaksanakan dalam satu kali pertemuan atau lebih.

\begin{tabular}{|c|c|c|c|c|}
\hline No & Kategori & Skor & $\mathrm{F}$ & $\begin{array}{c}\text { Frekuensi Relatif } \\
(\%)\end{array}$ \\
\hline 1 & Tinggi & $X \geq 57$ & 11 & $44 \%$ \\
\hline 2 & Sedang & $43 \leq X<57$ & 11 & $44 \%$ \\
\hline 3 & Rendah & $x<43$ & 3 & $12 \%$ \\
\hline \multicolumn{3}{|c|}{ Jumlah } & 25 & $100 \%$ \\
\hline
\end{tabular}

1. Pemahaman dan Kesiapan Guru terhadap Pelaksanaan Penilaian sesuai dengan tabel di bawah ini: Tabel 10. Pemahaman Guru terhadap Pelaksanaan Penilaian

Pemahaman guru terhadap penilaian hasil belajar masuk dalam kategori sedang dan tinggi masing-masing 11 orang atau sebesar $44 \%$. Sedangkan Kesiapan Guru dalam melaksanakan Penilaian Hasil Belajar sesuai tabel di bawah ini:

Tabel 11. Kesiapan Guru Melaksanakan Penilaian
Hasil Belajar

\begin{tabular}{|c|c|c|c|c|}
\hline No & Kategori & Skor & $\mathrm{F}$ & $\begin{array}{c}\text { Frekuensi Relatif } \\
(\%)\end{array}$ \\
\hline 1 & Tinggi & $X \geq 73$ & 9 & $36 \%$ \\
\hline 2 & Sedang & $47 \leq X<73$ & 13 & $52 \%$ \\
\hline 3 & Rendah & $X<47$ & 3 & $12 \%$ \\
\hline \multicolumn{3}{|c|}{ Jumlah } & 25 & $100 \%$ \\
\hline
\end{tabular}

Tabel di atas menunjukkan bahwa Kesiapan Guru melaksanakan hasil belajar masuk kategori sedang sebanyak

13 orang atau sebesar $52 \%$. Dalam Permendikbud Nomor 104 Tahun 2014 tentang pedoman penilaian hasil belajar oleh pendidik pada pendidikan dasar dan pendidikan menengah juga dijelaskan bahwa Penilaian Hasil Belajar oleh Pendidik adalah proses pengumpulan informasi/bukti tentang capaian pembelajaran peserta didik dalam kompetensi sikap spiritual dan sikap sosial, kompetensi pengetahuan, dan kompetensi keterampilan yang dilakukan secara terencana dan sistematis, selama dan setelah proses pembelajaran. Dari pemahaman terhadap penilaian hasil belajar ini diharapkan guru mampu melaksanakan penilaian dengan baik sesuai dengan tuntutan Kurikulum 2013.

2. Faktor Pendukung dan Penghambat Implementasi Kurikulum2013

Dalam penelitian ini ditemukan Faktor Pendukung dan Penghambat Implementasi Kurikulum 2013 di Kabupaten Tegal.

1. Faktor pendukung implementasi Kurikulum 2013 sebagai berikut:

a. Kesesuaian kompetensi pendidik dengan kurikulum 2013 sangat penting. Sesempurna apapun Kurikulum 2013 tanpa diimbangi kualitas pendidik yang 
mumpuni dalam mengimplementasikan Kurikulum tersebut, maka hanya akan ada dalam bentuk dokumen saja. Dalam rangka menyesuaiakan kompetensi pendidik dengan kurikulum, maka pemerintah telah melakukan sosialisasi dan pelatihan berkaitan dengan implementasi Kurikulum 2013.

Ketersediaan buku teks memiliki peranan penting dalam menunjang terhadap kesuksesan implementasi Kurikulum 2013 disamping sebagai bahan ajar dan sumber belajar. Bahan ajar atau materi pembelajaran

\section{(instructional}

materials) adalah pengetahuan, keterampilan, dan sikap yang harus dipelajari siswa dalam rangka mencapai standar kompetensi yang telah ditentukan. Secara terperinci, jenis-jenis materi pembelajaran terdiri dari pengetahuan (fakta, konsep, prinsip, prosedur), keterampilan, dan sikap atau nilai. Sedangkan Sumber belajar adalah segala sesuatu atau daya yang dapat dimanfaatkan oleh guru, baik secara terpisah maupun dalam bentuk gabungan, untuk kepentingan belajar mengajar dengan tujuan meningkatkan efektivitas dan efisiensi tujuan pembelajaran baik dalam bentuk cetakan (buku), video, format perangkat lunak atau kombinasi dari berbagai format yang dapat digunakan oleh siswa ataupun guru.

b. Pemerintah melalui Dinas DIKPORA Kabupaten Tegal melakukan pembinaan dan pengawasan dalam bentuk pendampingan, monitoring dan evaluasi terhadap sekolahsekolah yang sudah menerapkan Kurikulum 2013. Diantara empat sekolah menengah kejuruandi Kabupaten Tegal yang telah mengimplementaiskan Kurikulum 2013, SMK N 2 adiwerna merupakan sekolah yang ditunjuk sebagai sekolah pendamping Kurikulum 2013 bagi sekolahsekolah lain di Kabupaten Tegal.

Sebagai sekolah pendamping, tidak mengherankan jika dalam perangkingan hasil instrumen tes pemahaman dan kesiapan guru Bahasa Indonesia se-Kabupaten Tegal SMK N 2 adiwerna menempati peringkat tertinggi dengan nilai rata-rata 61 , disusul SMK N 1 Slawi dengan rata-rata nilai 60, SMK N 1 Dukuhturi dengan ratarata nilai 58, dan SMK N 1 Adiwerna dengan rata-rata nilai 54 .

Penguatan manajemen dan budaya sekolah berperan penting dalam menunjang kesuksesan

implementasi Kurikulum 2013 terutama kesiapan guru. Dengan manajemen sekolah yang bagus serta budaya tertib dan disiplin terlebih pada bidang administrasi perangkat mengajar guru, makaimplementasi Kurikulum 2013 tidak akan mengalami banyak kesulitan. Apabila dilihat rata-rata hasil tes instrumen pemahaman dan kesiapan guru yang berjumlah 57, rata-rata nilai kesiapan lebih besar dari pada ratarata nilai pemahaman. Rata-rata nilai pemahaman 51 dan rata-rata nilai kesiapan 64. Hal ini sangat dipengaruhi oleh faktor manajemen 


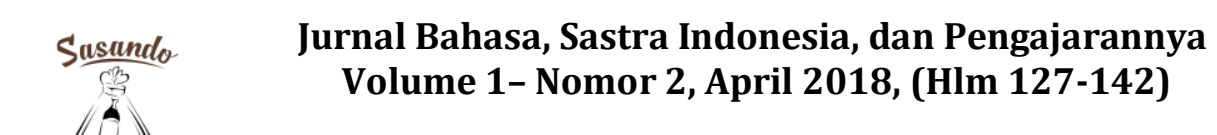

Available online at: http://sasando.upstegal.ac.id

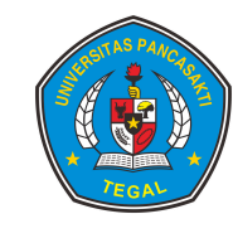

dan budaya sekolah. Pemahaman lebih bersifat individu, sedangkan kesiapan disamping bersifat individu juga dipengaruhi oleh manajemen dan budaya guru diterapkan di sebuah lembaga sekolah.

c. Sebagian besar Sekolah Menengah Kejuruan di Kabupaten Tegal sudah memiliki sarana dan prasarana yang memadai, misalnya: adanya laboratorium komputer, LCD proyektor, perpustakaan, jaringan internet, dan banyaknya Guru yang menguasai komputer (hasil observasi penelitian). Empat sekolah yang menerapkan Kurikulum 2013 pada tahun pelajaran 2016-2017 merupakan sekolah yang notabene favorit. Sehingga sekolah-sekolah tersebut tidak mengalami kesulitan dalam hal sarana dan prasarana pendukung untuk mensukseskan Kurikulum 2013.

2. Faktor penghambat implementasi Kurikulum 2013 sebagai berikut:

Pemahaman kurikulum 2013 yang belum menyeluruh membuat guru mata pelajaran bahasa Indonesia balum dapat melaksanakan kurikulum 2013 secara utuh dan maksimal baik secara konsep maupun prakteknya. Pemahaman yang lemah ini terutama berkaitan dengan pemahaman rencana pelaksanaan pembelajaran (nilai rata-rata 42), buku teks (nilai rata-rata 46), penilaian hasil belajar (nilai rata- rata 55) dan kesiapan pelaksanan pembelajaran (nilai rata-rata 56). Hal ini dibuktikan dengan masih adanya guru yang kesulitan dalam memilih pendekatan dalam proses pembelajaran.

3. Permasalahan seputar buku teks merupakan sumber penghambat belajar, karena buku dapat membantu guru dan siswa untuk memahami materi yang disampaikan.

4. Administrasi Kurikulum 2013 yang membebani guru. Kurikulum 2013 sebagai hasil pengembangan terhadap kurikulum KTSP berimplikasi juga terhadap beban administrasi perangkat mengajar yang harus dipenuhi oleh guru. Sebagian besar guru responden mengalami kesulitan dalam menyusun administrasi kurikulum 2013 terutama dalam menganalisis KD, menyusun RPP, dan menyusun penilaian.

a. Penggunaan sarana dan prasarana kurang maksimal. Secara umum, sarana dan prasarana penunjang Kurikulum 2013 di sekolah menengah kejuruan se-Kabupaten Tegal sudah terpenuhi. Namun, penggunaan sarana dan prasarana tersebut masih belum maksimal. Hal ini disebabkan antara lain masih adanya guru yang belum menguasai komputer sehingga sarana dan prasarana yang sudah ada tidak dapat berfungsi secara maksimal.

\section{SIMPULAN}

Simpulan dari hasil penelitian tentang Pemahaman dan Kesiapan Guru Mata Pelajaran Bahasa Indonesia SMK SeKabupaten Tegala adalah sebagai berikut. 1. Pemahaman guru terhadap Kurikulum 2013 sebagian besar masuk dalam kategori sedang yaitu 
sebanyak 12 guru atau $48 \%$. Selanjutnya guru yang masuk dalam kategori rendah sebanyak 8 guru atau $32 \%$, dan guru yang masuk dalam kategori tinggi sebanyak 5 guru atau 20\%. Frekuensi terbesar terdapat pada kategori sedang, sehingga dapat disimpulkan bahwa pemahaman guru terhadap Kurikulum 2013 adalah sedang.

2. Kesiapan guru untuk mendukung implementasi Kurikulum 2013 sebagian besar masuk dalam kategori sedang yaitu sebanyak 13 guru atau $52 \%$, selanjutnya masuk dalam kategori rendah sebanyak 10 guru atau $40 \%$ dan guru yang masuk dalam kategori tinggi sebanyak 2 guru atau 8\%. Frekuensi terbesar terdapat pada kategori sedang, sehingga dapat disimpulkan bahwa kesiapan guru untuk mendukung implementasi Kurikulum 2013 adalah sedang.

3. Komponen kesiapan guru untuk menyusun RPP merupakan nilai ratarata tertinggi dalam instrumen tes dengan nilai 81. Kedua, pemahaman guru terhadap pelaksanaan pembelajaran dengan nilai 61. Ketiga, kesiapan guru untuk melaksanakan penilaian hasil belajar dengan nilai 59. Keempat, kesiapan guru untuk menggunakan buku teks dengan nilai 58. Kelima, kesiapan guru untuk melaksanakan pembelajaran dengan nilai 56. Keenam, pemahaman guru terhadap penilaian hasil belajar dengan nilai 55. Ketujuh, pemahaman guru terhadap penggunaan buku teks dengan nilai 46. Dan terakhir pemahaman guru terhadap penyusunan RPP dengan nilai 42 .

4. Dalam perangkingan hasil instrumen tes pemahaman dan kesiapan guru Bahasa Indonesia se-Kabupaten Tegal SMK N 2 Adiwerna menempati peringkat tertinggi dengan nilai rata- rata 61 , disusul SMK N 1 Slawi dengan ratarata nilai 60, SMK N 1 Dukuhturi dengan rata-rata nilai 58, dan SMK $\mathrm{N} 1$ Adiwerna dengan rata- rata nilai 54.

\section{SARAN}

Atas dasar simpulan hasil penelitian di atas, maka saran yang dapat peneliti sampaikan adalah sebagai berikut.

1. Bagi sekolah seyogyanya lebih memfasilitasi guru untuk mengikuti kegiatan yang diselenggarakan pemerintah yang berkaitan dengan sosialisasi dan pelatihan Kurikulum 2013 untuk meningkatkan pemahaman dan kesiapan guru untuk mendukung implementasi Kurikulum 2013

2. Mereview kembali pemahaman terhadap konsep Kurikulum 2013 sehingga memiliki pemahaman yang menyeluruh dan tidak sepotongpotong.

3. Mereview kembali penguasaannya terhadap buku teks, pemahamannya terhadap penyusunan administrasi kurikulum 2013 terutama dalam menganalisis KD, menyusun RPP, dan menyusun penilaian hasil belajar dan memaksimalkan penggunaan saranadan prasarana yang ada di sekolah dengan cara meningkatkan penguasaannya terhadap teknologi dan 


\section{Susundo

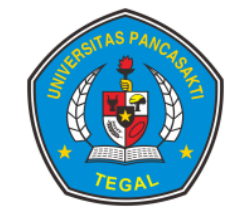

informasi sehingga fungsi sarana dan prasarana sebagai penunjang terhadap kesuksesan implementasi Kurikulum 2013

4. Bagi Pemerintah melalui Dinas DIKPORA Kabupaten Tegal seyogyanya lebih meningkatkan pembinaan dan pengawasan baik dalam bentuk pendampingan, monitoring maupun evaluasi terhadap sekolah-sekolah yang menerapkan Kurikulum 2013.

\section{DAFTAR PUSTAKA}

Arikunto, Suharsimi. (2014). Evaluasi Program Pendidikan. Jakarta: Bumi Aksara.

Arikunto, Suharsimi. (2012). Dasar-Dasar Evaluasi Pendidikan (edisi revisi). Cet. IX; Jakarta: Bumi Aksara.

Arikunto, Suharsimi. (2014). Manajemen Penelitian. Jakarta: Rineka Cipta.

Azwar, Saifuddin. 2015. Pnyusunan Skala Psikologi Edisi 2.

Yogyakarta: Pustaka Pelajar.

Budiman, Arif Sukadi. (1946). Beberapa Aspek Pengembangan Sumber Belajar. Cet. I; Jakarta: Mediyatama Sarana Perkasa.

Dalyono. (2015). Psikologi Pendidikan. Jakarta: PT Rineka Cipta.

Departemen Pendidikan dan Kebudayaan. (1998). Tata Bahasa Baku Bahasa Indonesia (Edisi ketiga). Jakarta: Depdikbud.
Departemen Pendidikan dan Kebudayaan. (2003). Undang-Undang No 20 Tahun 2003 tentang Sistem Pendidikan Nasional. Jakarta: Depdikbud.

Departemen Pendidikan dan Kebudayaan. (2013).

Permendikbud Nomor 60

tahun 2014 tentang Kurikulum 2013 Sekolah

$h$ Menenga

Kejuruan/Madrasah

ah Kejuruan. Jakarta: Depdikbud.

Departemen Pendidikan dan Kebudayaan. (2013). Salinan Lampiran Peraturan Menteri Pendidikan dan Kebudayaan No.

69 Tahun 2013. Jakarta: Depdikbud.

Departemen Pendidikan dan Kebudayaan. (2013). Insrtumen monitoring dan evaluasi implementasi kurikulum 2013 tingkat sekolah menengah atas (SMA). Jakarta: Depdikbud.

Departemen Pendidikan Nasional.(2008) Kamus Besar Bahasa Indonesia Pusat Bahasa. Jakarta: PT Gramedia Pustaka Utama.

Evanita, E.L. (2013). Analisis Kompetensi Pedagogik dan Kesiapan Guru Sekolah Menengah Atas dalam Mendukung Implementasi Kurikulum 2013. Skripsi Sarjana 


\section{Sasando

pada Fakultas Matematika dan Ilmu Pengetahuan Alam UNNES Semarang: tidak diterbitkan.

Hamalik, O. (2010). Manajemen Pengembangan Kurikulu m. Bandung: Remaja Rosdakarya.

Hamid, H. (2012) Pengembangan Kurikulum Pendidikan. Bandung: CV Pustaka Setia.

Heryadi, Dedi. (2015). Metode Penelitian Pendidikan Bahasa.Bandung: Pustaka Billah.

Kurinasih-Berlin Sani, I. (2014), Implementas Kurikulum 2013 Konsep \& Penerapan. Surabaya: kata pena.

Nuh, M. (2013). Kurikulum 2013. (Online). Tersedia: http://edukasi.kompas.com/ $\mathrm{read} / 2013 / 03 / 08 / 08205286 /$ Kuri kulum.2013.(27 Mei 2016).

Nurgiyantoro B, Gunawan, Marzuki,. (2012). Statistik Terapan . Cet. V; Yogyakarta: Gadjah Mada Press.

Mulyasa E. (2015). Guru dalam Implementasi Kurikulum 2013. Bandung: Rosdakarya.

Mulyasa E. (2013). Menjadi Guru Profesionl. Bandung: Remaja Rosdakarya.

Mulyasa E. (2015). Pengembangan dan Implementasi Kurikulum 2013. Bandung: Rosdakarya.
Oliva, Peter F. (1992). Developing The Curriculum. New York: Hirper Collen Publisher.

Pertiwi, I. (2015) Tingkat Pemahaman Guru Terhadap Penilaian Hasil Belajar Berdasarkan Kurikulum 2013 Pada Mata Pelajaran Ekonomi Di Sekolah Menengah Atas (SMA) Negeri Se - Kabupaten Sleman. Skripsi Sarjana Pada Fakultas Ekonomi UNY Yogyakarta: tidak diterbitkan.

Purwanto, Ngalim. (1987). Prinsip-prinsip dan teknis: Evaluasi Pengajaran, Bandung: Rosdakarya.

Purwanto, Ngalim. (1987). Prinsip-prinsip dan teknis: Evaluasi Pengajaran, Bandung: Rosdakarya.

Sanjaya, Wina. (2013). Strategi Pembelajaran:

Berorient asi Standar Proses Pendidikan. Jakarta: Kencana Prenadamedia Group.

Setyawan, D.B. (2014). Analisis Kesiapan Guru Mata Pelajaran Ekonomi Sekolah Menengah Atas Se- Kabupaten Banjarnegara Dalam Mendukung Implementasi Kurikulum 2013. Penelitian ini dilakukan di SMA se-Kabupaten Banjarnegara. Skripsi Sarjana pada Fakultas Ekonomi UNY Yogyakarta: tidak diterbitkan.

Sugiyono. (2014). Cara Mudah Menyusun Skripsi, Tesis, dan Disertasi. Bandung: Alfabeta. 
Sugiyono. (2013). Metode Penelitian

Pendidikan. Bandung: Elfabeta.

Sujiono, Anas. (1987). Pengantar Statistik Pendidikan. Jakarta: PT Raja Grafindo Persada.

Sumantri, Mulyani. (1998). Kurikulum dan Pengajaran. P2LPTK Depdikbud, Jakarta.

Widoyoko, Eko Putro . (2015). Evaluasi Program Pembelajaran: Panduan Praktis bagi Pendidik dan calon pendidik. ; Yogyakarta: Pustaka Pelaj

\section{PROFIL SINGKAT}

Ghufroni lahir di Kecamatan Pangkah, kabupaten Tegal, 5 Januari 1986.

Menempuh pendidikan S1 di IKIP Muhammadiyah Jakarta, lulus pada tahun 1994. Menempuh studi S2 di Universitas Muhammadiyah Purwokerto lulus pada tahun 2017. Berprofesi sebagai dosen di Universitas Muhadi Setiabudi Brebes dan menjabat sebagai ketua program studi PBSI hingga saat ini. 
